\title{
4. 心不全マーカーと心血管リスク予測因子としての ナトリウム利尿ペプチド
}

蔦 本 尚 慶* 堀 江 稔*

\section{1．心不全における神経液性因子とバイオマーカー}

収縮機能の低下した心不全患者において, 蓄積された大 規模臨床研究の結果, ACE 阻害薬, アンジオテンシン受容 体拮抗薬, $\beta$ 遮断薬, 抗アルドステロン薬, 心室再同期療 法（除細動器付）を病態に応じて選択することで予後が改 善することが明らかになった (Fig. 1)。これら大規模臨床 試験の結果は, レニン・アンジオテンシン・アルドステロ ン（RAAS）系や交感神経系の経路を遮断することによっ て, 心保護作用を増強させる薬剤が心不全の予後を改善す ることが示され，神経体液性因子のバランスの破綻が重要 な因子であることが証明された。したがって，バイオマー カーとして神経体液性因子を測定することで心不全重症 度一予後一治療効果を評価できる可能性がある。「心臓刺 激因子」としての RAAS 系, 交感神経系, エンドセリン, 「心保護因子」として ANP，BNPがある，BNPに代表さ れるナトリウム利尿関連ペプチド濃度測定 ( $\mathrm{N}$ 端-proBNP など）は心不全の診断と評価に有用な生化学マーカーであ ることはほほ確立されたといってよい（Fig. 2).

\section{2. 大規模臨床試験における BNP, N 端-proBNP}

重症慢性心不全患者における $\beta$ 遮断薬 carvedilol の有用 性を検討した COPERNICUS 研究では, エントリーされた 2,289 例のうち, 1,048 名において開始前に $\mathrm{N}$ 端-proBNP 濃度が測定され, プラセボ群, carvedilol 群ともに N 端proBNP 濃度の高い患者ほど予後が不良であることが報告 された ${ }^{1)}$ 。さらには, プラセボ群, carvedilol 群ともに N 端proBNP 濃度が数力月間にわたり繰り返し測定されてお り，プラセボ群では経過中変動を認めなかったが, carvedilol 群では $\mathrm{N}$ 端-proBNP 濃度は有意に低下した。した がって, N 端-proBNP 濃度は重症慢性心不全患者の予後 推測因子として有用であり，またこれら重症患者において carvedilol の治療効果判定に有用であることが示された2).

Val-HeFT 試験においても, valsartan 群とプラセボ群で 経時的にBNP が測定された。 その結果, プラセボ群では, BNP は経時的に上昇したのに比較して, valsartan 群では BNP は経時的に低下し, サロゲートマーカーとしての妥 当性が示された (Fig. 3)。またこの試験では, BNP と N

* 滋賀医科大学呼吸循環器内科 ₹ 520-2192 大津市瀬田月輪町

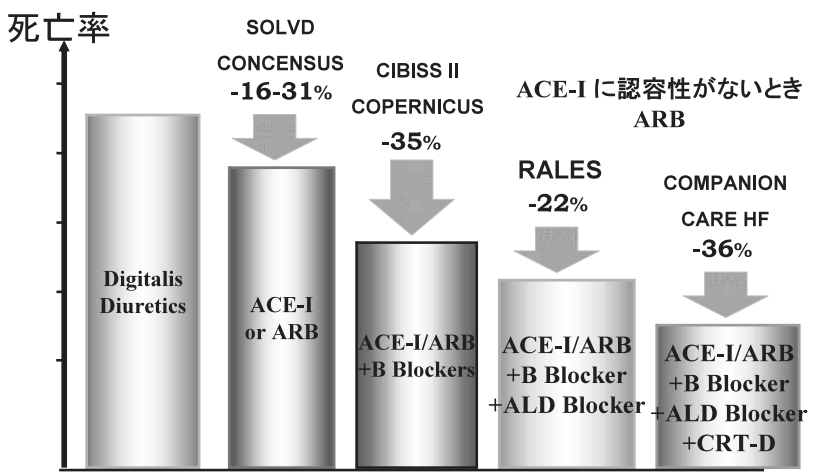

Fig. 1 慢性心不全 $(\mathrm{EF}<40 \%)$ に対する内科治療の変遷 (死亡率への影響)

(Ellenbogen KA, et al. JACC. 2005；46：2201 を改変)

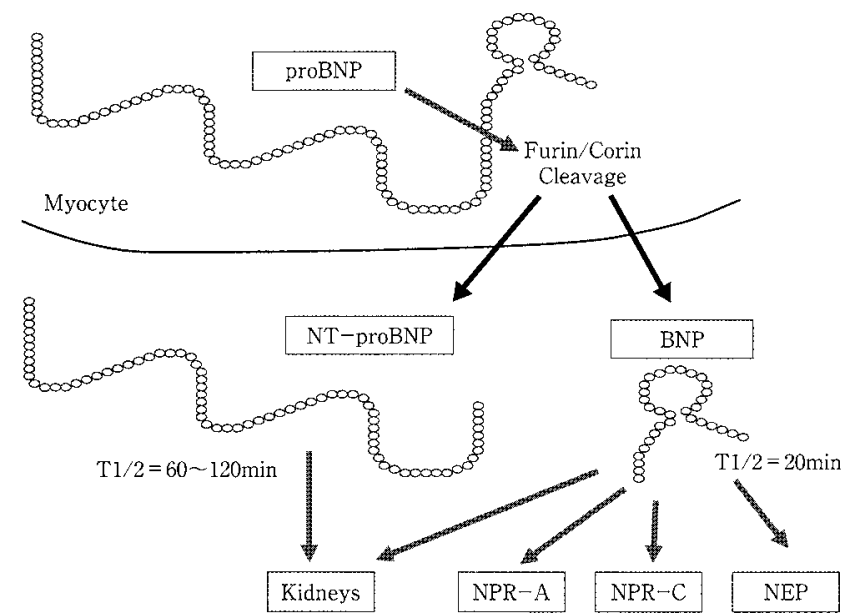

Fig. 2 BNP，N 端-proBNPの分泌と代謝

NPR-A：ナトリウム利尿ペプチド A 受容体, NPR-C : クリア ランス受容体, NEP : neutral endopeptidases,

NT-proBNP : N 端-proBNP

端-proBNP 濃度のどちらが心不全患者の重症度や予後評 価として有用かが評価された。 その結果によると, 総死亡 については同等であったが, 心不全による死亡や再入院で は N 端-proBNP 濃度の有用性が示唆された。ささらには,

日常診療では治療経過で, 観察期の BNP と N 端-proBNP 濃度の值とともに, 経過中の変化率が予後と関係すること が示されだ. 


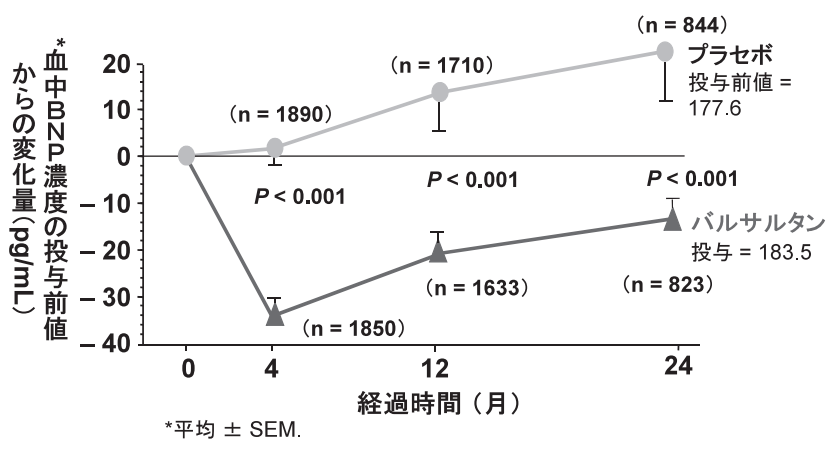

Fig. 3 血中 BNP 濃度の経時的変化 (Val-HeFT)

(Latini R, et al. [abstract]. Circulation. 2001 より改変)

BNP のサロゲートマーカーとしての可能性は, 最近の ALOFT 研究においても報告されている。レニン阻害薬で ある aliskirenの投与前後で, 従来治療 +プラセボ群に比 して, aliskiren の投与群で BNP, N 端-proBNP ともに改 善を認めている。このような結果が，予後改善効果につな がる可能性があり現在臨床試験が進行中である，収縮機能 の保持された心不全患者の特徵は，高齢，女性が多く，今 まで予後改善効果が明らかにされた治療薬はない，最近発 表された I-PRESERVE 試験でも，irbesartan はプラセボ と予後に対する効果は同等であっだ)。この試験でも，試 験開始時と 6 力月後に $\mathrm{N}$ 端-proBNP 濃度が測定されてい るが，両群間に N 端-proBNP 濃度に対する効果にも差は 認められていない，また，BNP を低下する治療がすべて 予後を改善するわけでもない，ス夕チンにはBNP を低下 するとの報告があり，期待されたが現時点で予後を改善し たとの報告はない．

\section{BNP と N 端-proBNP の共通点}

心臟からの BNP, N 端-proBNP 分泌を規定する因子に ついて，血行動態，推定 GFR 值，年齢，性，BMI，心房細 動の有無, ヘモグロビンなどを含めた多変量解析の結果, 左室拡張末期圧と左室駆出率の 2 つが独立した規定因子で あった。この結果は, BNP, N 端-proBNP ともに血行動態 指標の客観的指標として有用な心不全のバイオマーカーで あること支持している。一方，末梢血中の BNP と N 端proBNP は, 左室拡張末期圧, 左室駆出率のほかに, 左室 心筋重量，貧血（ヘモグロビン），推定 GFR が独立した規 定因子であった ${ }^{5,6)}$. したがって，末梢血の BNP， N 端proBNP 濃度は，心腎機能の異常を反映するバイオマー カーと言ったほうが正確である（Fig. 4A，B）。

\section{4. 心不全診断（左室拡張末期圧高值）や治療効果判定と \\ BNP，N 端-proBNP 濃度}

BNP，N 端-proBNP 濃度が心不全診断や重症度評価に 有用なバイオマーカーである根拠の 1 つは，左室拡張末期 圧（前負荷）と正相関し侵襲的な検査をしなくても左室拡 張末期圧高值（>12 mmHg）をある程度予測可能な点にあ

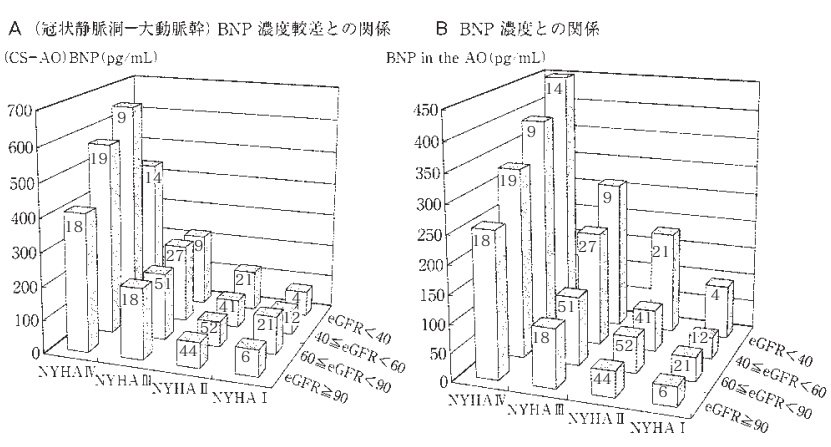

Fig. 4 NYHA 心機能分類と推定 GFR 值の BNP 濃度 と分泌に及ぼす影響（文献 6）より引用）

$\mathrm{AO}$ : 大動脈幹, $\mathrm{CS}$ : 冠状静脈洞, グラフの数字は症例数

$ろ^{6)}$ ．慢性心不全患者 326 名による検討では，左室拡張末 期圧高值（>12 mmHg）を予測する BNP, N 端-proBNP 濃度のカットオフ值が $\mathrm{CKD}$ 合併の有無で異なることが示 された．推定 GFR 值 $\geqq 60 \mathrm{~mL} / \mathrm{min}$ の $\mathrm{CKD}(-)$ 患者にお いては, BNP, N 端-proBNP 濃度のカットオフ值はそれぞ れ $63 \mathrm{pg} / \mathrm{mL}, 295 \mathrm{pg} / \mathrm{mL}$. 推定 GFR 值 $<60 \mathrm{~mL} / \mathrm{min}$ の CKD (+ ) 患者においては, BNP, N 端-proBNP 濃度の カットオフ值はそれぞれ $220 \mathrm{pg} / \mathrm{mL}, 699 \mathrm{pg} / \mathrm{mL}$ と上方 に設定する必要が示唆された ${ }^{5,6)}$ 。この結果は, MacCullough らの, 腎機能障害を伴う場合に推定 GFR が $60 \mathrm{~mL} /$ min 未満の患者においては，心不全診断における BNP の カットオフ值を $100 \mathrm{pg} / \mathrm{mL}$ から $200 \mathrm{pg} / \mathrm{mL}$ 前後に上方修 正すべきとの報告を支持している7).

重症心不全患者の治療効果判定には, 最近 ANP, BNP, $\mathrm{N}$ 端-proBNP などが左室拡張末期圧の予測指標として使 用されることが多くなっている。実際に, nitroglycerin や nicorandil（シグマート ${ }^{\circledR}$ ) の血行動態的耐性の指標として 有用であると報告されている，パンプ治療中の評価には ANP は使用できないのは当然であるが, BNP 濃度は受容 体との競合のよるためか約 $20 \%$ 見かけ上，上昇する可能性 があり N 端-proBNP 濃度が有用である゙8.

\section{文献}

1) Hartmann F, et al. Eur J Heart Fail 2004 ; 6 : 343-50.

2) Masson S, et al ; Val-HeFT Investigators. Clin Chem 2006 ; 52 : 1528-38.

3) Masson S, et al ; Val-HeFT Investigators. J Am Coll Cardiol $2008 ; \mathbf{5 2}: 997-1003$.

4) Massie BM, et al ; I-PRESERVE Investigators. $N$ Engl J Med $2008 ; 359: 2456-67$.

5) Tsutamoto T, et al. Eur J Heart Fail $2007 ; 9$ : 667-73.

6) Tsutamoto T, et al. J Am Coll Cardiol 2006 ; $47: 582-6$.

7) McCullough PA, et al ; Breathing Not Properly Multinational Study Investigators. Am J Kidney Dis $2003 ; 41: 571-9$.

8) Nishiyama K, et al. Int Heart J 2009 ; 50 : 183-90. 